\title{
Nano-Enabled Products: Challenges and Opportunities for Sustainable Agriculture
}

\author{
Vishnu D. Rajput ${ }^{1, *(\mathbb{D}}$, Abhishek Singh $^{2}{ }^{(\mathbb{D}}$, Tatiana Minkina ${ }^{1}\left(\mathbb{D}\right.$, Sapna Rawat $^{3}$, Saglara Mandzhieva ${ }^{1}{ }^{(}$, \\ Svetlana Sushkova ${ }^{1}{ }^{1}$, Victoria Shuvaeva ${ }^{1}$, Olga Nazarenko ${ }^{1}$, Priyadarshani Rajput ${ }^{4}$, Komariah ${ }^{5}$, \\ Krishan K. Verma ${ }^{6}{ }^{(}$, Awani Kumar Singh ${ }^{7}$, Mahesh Rao ${ }^{8}$ and Sudhir K. Upadhyay ${ }^{9}$
}

1 Academy of Biology and Biotechnology, Southern Federal University, 344090 Rostov-on-Don, Russia; tminkina@mail.ru (T.M.); msaglara@mail.ru (S.M.); terra_rossa@mail.ru (S.S.); v_shuvaeva@mail.ru (V.S.); nazarenkoo@mail.ru (O.N.)

2 Department of Agricultural Biotechnology, College of Agriculture, Sardar Vallabhbhai Patel University of Agriculture and Technology, Meerut 250110, India; intmsc.abhi@gmail.com

3 Department of Botany, University of Delhi, Delhi 110007, India; rawatsapna61@gmail.com

4 The Smart Materials Research Institute, Southern Federal University, 344090 Rostov-on-Don, Russia; priyadarshanirajput22@gmail.com

5 Soil Science Department, Faculty of Agriculture, Sebelas Maret University, Surakarta 57126, Indonesia; komariah@staff.uns.ac.id

6 Guangxi Academy of Agricultural Sciences, Nanning 530007, China; drvermakishan@gmail.com

7 Centre for Protected Cultivation, ICAR-Indian Agricultural Research Institute, New Delhi 110012, India; singhawani5@gmail.com

8 Pusa Campus, ICAR-National Institute for Plant Biotechnology (NIPB), New Delhi 110012, India; mraoicar@gmail.com

check for updates

Citation: Rajput, V.D.; Singh, A.; Minkina, T.; Rawat, S.; Mandzhieva, S.; Sushkova, S.; Shuvaeva, V.;

Nazarenko, O.; Rajput, P.; Komariah; et al. Nano-Enabled Products: Challenges and Opportunities for Sustainable Agriculture. Plants 2021, 10, 2727. https://doi.org/10.3390/ plants10122727

Academic Editor: Per Kudsk

Received: 11 November 2021 Accepted: 8 December 2021 Published: 11 December 2021

Publisher's Note: MDPI stays neutral with regard to jurisdictional claims in published maps and institutional affiliations.

Copyright: (c) 2021 by the authors. Licensee MDPI, Basel, Switzerland. This article is an open access article distributed under the terms and conditions of the Creative Commons Attribution (CC BY) license (https:/ / creativecommons.org/licenses/by/ $4.0 /)$.
9 Department of Environmental Science, V.B.S. Purvanhal University, Jaunpur 222003, India; sku.env.lko@gmail.com

* Correspondence: rajput.vishnu@gmail.com

Abstract: Nanotechnology has gained popularity in recent years owing to its established potential for application and implementation in various sectors such as medical drugs, medicine, catalysis, energy, material, and plant science. Nanoparticles (NPs) are smaller in size (1-100 nm) with a larger surface area and have many fruitful applications. The extraordinary functions of NPs are utilized in sustainable agriculture due to nano-enabled products, e.g., nano-insecticides, nano-pesticides, and nano-fertilizers. Nanoparticles have lately been suggested as an alternate method for controlling plant pests such as insects, fungi, and weeds. Several NPs exhibit antimicrobial properties considered in food packaging processes; for example, Ag-NPs are commonly used for such purposes. Apart from their antimicrobial properties, $\mathrm{NPs}$ such as $\mathrm{Si}, \mathrm{Ag}, \mathrm{Fe}, \mathrm{Cu}, \mathrm{Al}, \mathrm{Zn}, \mathrm{ZnO}, \mathrm{TiO}_{2}, \mathrm{CeO}_{2}, \mathrm{Al}_{2} \mathrm{O}_{3}$, and carbon nanotubes have also been demonstrated to have negative impacts on plant growth and development. This review examines the field-use of nano-enabled products in sustainable agriculture, future perspectives, and growing environmental concerns. The remarkable information on commercialized nano-enabled products used in the agriculture and allied sectors are also provided.

Keywords: nanotechnology; nano-insecticide; nano-fertilizer; nano-pesticide; health risk; soil; plant

\section{Introduction}

The world's population presently stands at almost 7.9 billion (2021), with a significant proportion residing in developing countries, especially in Asia, with approximately $50 \%$. A large bulk of people here confront daily food shortages owing to environmental effects or political uncertainties, whereas in the industrialized world, the drive is to plant droughtand pest-resistant crops, which also boost yields [1,2]. The annual meeting of the American Physical Society was held on 29 December 1959, at the California Institute of Technology, and Richard Feynman delivered a speech entitled "There's Plenty of Room at the Bottom, 
An Innovation to Enter a New Field of Physics" [3], which suggested manipulating the matter on an atomic scale and developed the idea of nanotechnology (NT; nano: N, technology: T). However, Norio was the first who used this term in 1974 [4].

Nanotechnology has taken a big step forward, and this is reflected in the money invested in development and research in this field. A budget of $\$ 27$ billion was proposed by the United States National Nanotechnology Initiative (NNI) in the year 2019; Nano-Mech, a leading NPs manufacturing company, received \$10 million from Saudi Aramco Energy Ventures (SAEV); and \$350 million was received by the Massachusetts Institute of Technology to develop a state-of-the-art nanoscale center called "MIT nano" [5]. To accomplish the Zero Hunger goal, the United Nations' aim for sustainable development to be reached by 2030 , there is an urgent requirement for thorough variations in conventional agriculture practices. Such changes can be achieved by employing NTs innovations $[6,7]$.

Numerous strategies have been developed by researchers in the last several decades to replace conventional agriculture practices. Of them, NT is one evolving technique that is expected to improve modern agriculture in sustainable ways, such as crop productivity via ameliorating the consequences by increasing plant nutrition, precision farming, water use efficiency, crop protection against pests and diseases by devolving nano-enabled formulations, and environmental restoration of degraded sites by nano-bioremediation [8-10]. The distinctive physicochemical properties of NPs greatly help them to be suitable for diverse applications in almost all industries and received extensive attention in agriculture together with numerous other field applications, i.e., biomedical, chemical, optical, pharmaceutical, food, cosmetics, and textile [11]. In addition, NPs are also used in fortifications $[7,12]$ and food processing [13].

It is documented that the nano-enabled products are already in commerce and being applied in sustainable agriculture such as nano-fertilizers [14], growth stimulators [15], soil-improving agents $[6,16,17]$, and nano-sensors [18] and have gained popularity as smart and controlled delivery materials. However, the rapid application of NPs has also raised concern for soil microbiota, accumulation in plants, and the threat to human health via the food chain [19]. The review focuses on the possibilities of safe application of nano-enabled products for sustainable agriculture and raises environmental concerns.

\section{Field Application of Nano-Enabled Products}

The practice of applying NPs in agriculture promises a bright future, but it is still in its infancy stage [20]. The synthesis of modified NPs for agricultural purposes has considerable potential to alter the perception of conventional agriculture [21,22]. It helps to solve persisting challenges in agriculture using advanced materials and technologies. Most of these problems are usually related to pesticides, herbicides, fertilizers, etc. and their optimal use. In plants, the distribution of NPs involves a characteristic route with multiple advantages [23].

Nanoparticles have a great capacity to protect plants owing to their essential features such as surface-to-volume ratio, size, and optical attributes [24]. A nice example of NPs application is nano-encapsulated fertilizers and pesticides dispensed via a method that distributes the content in a controlled manner $[25,26]$. This method is also site-specific. For the protection of non-target organisms and other collateral repairs, this highly efficient method is beneficial [27] and provides an effective defense mechanism when plants engage with pathogens by sending systemic compounds such as jasmonic acid, salicylic acid, benzothiadiazole, and others to the appropriate sites [28,29].

In agriculture, some other applications of NT can be seen, such as attenuating natural pesticides and biopesticides, and the measured and controlled release of fertilizers supported by NPs, micronutrients, nano-sensors, and organic fertilizers $[14,18,30]$. The nanotechnology products database (NPD) website, used to keep updated records on nano-enabled products, showed the total number of products to be 9245 manufactured by 64 countries via 2658 companies (https:/ / product.statnano.com/; accessed on 7 July 2021) in commercial production. Figure 1 illustrates various nano-enabled products 
and their application in different fields such as agriculture, automotive, construction, cosmetics, printing, petroleum, environment, textile, electronics, sports, fitness, environment, home appliances, renewable energy, food, medicine, and other nano-enabled products.

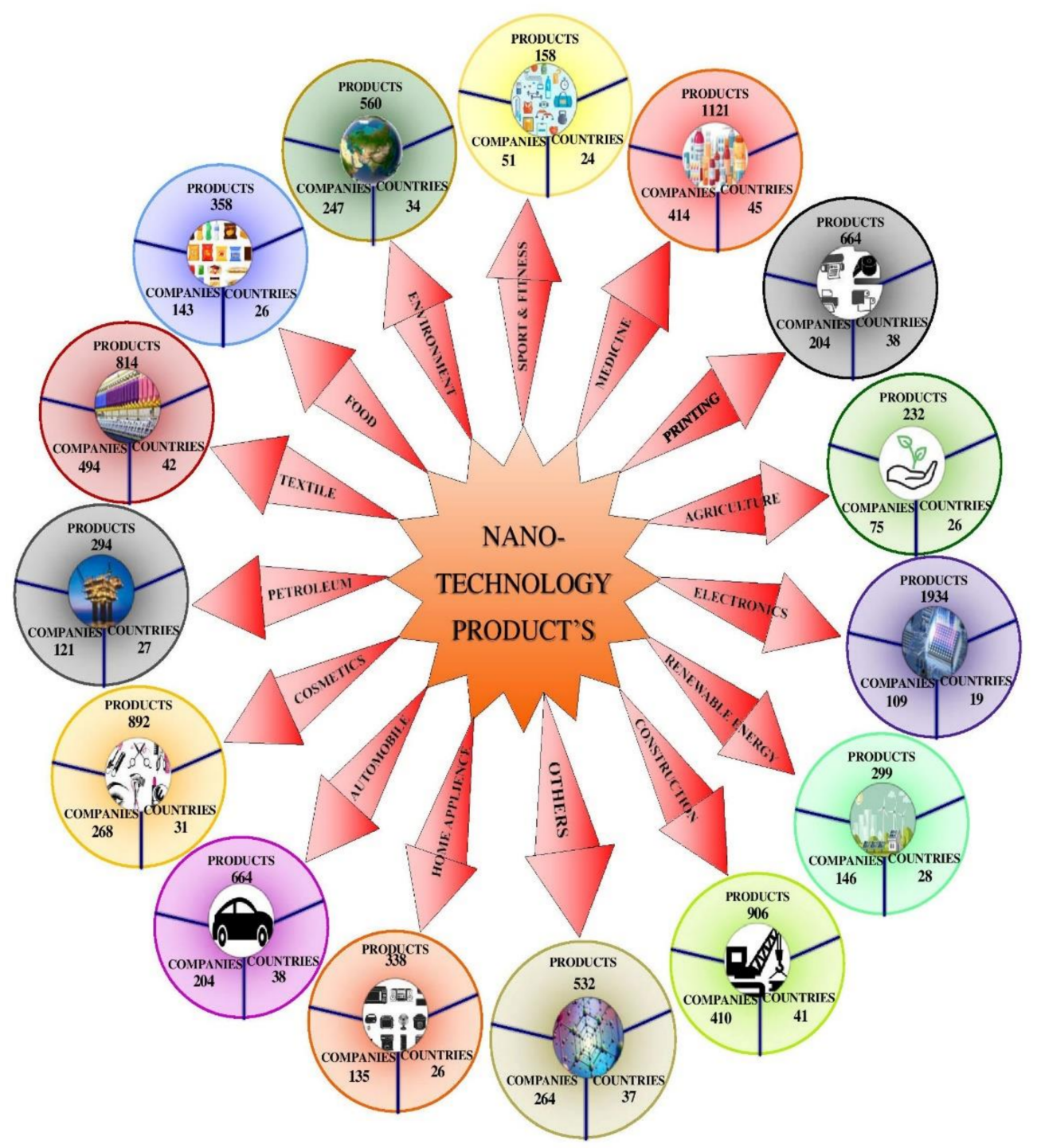

Figure 1. Representation of nanotechnology products, manufacturing firms, and countries involved.

In agriculture, more than 232 nano-enabled products are manufactured by 75 companies in 26 countries all over the world. These nano-enabled products are related to plant protection, fertilizers, soil improvement, plant breeding, and animal husbandry. Figure 1 illustrates applications of nano-enabled products in different fields, including agriculture. Similarly, in automotive industry manufacturing, a total of 664 nano-enabled products are manufactured by 204 companies in 38 countries. These nano-enabled products used in automotive industries are related to auto-additives, auto-parts, and maintenance. In the same way, more than 906 nano-enabled products produced by 410 companies in 41 countries are in use in construction industries. In the cosmetic industry, a total of 892 nano-enabled products are in use; in printing, 664; in textiles, 814; in electronics, 894; and in pharmaceutical companies, 1121 nano-enabled products are in use (Figure 1). Thus, nano-enabled products have a wide range of applications in various industries as described in Figure 1. 


\subsection{Nano-Enabled Products and Crop Protection}

Nowadays, fungicides, pesticides, herbicides, and fertilizers are applied in soil in inappropriate amounts through foliar application. Fungicides, pesticides, and herbicides are a mixture of chemical substrates that can be used to control, prevent, or destroy any pests, microbes, or unwanted herbs that infect crops and reduce crop production [22,31,32]. Algicides, herbicides, fungicides, pesticides, and plant disinfecting agents are the main nano-enabled products considered for crop protection nowadays. More recently, nanobased stretch films made with polyethylene have been developed for hay packing to protect crops against UV-rays and thunder and have been used in active food packaging systems to protect against Escherichia coli spoilage [33]. The 40 plant-protection, nano-enabled products are available in the commercial market in 12 countries and were developed by 16 companies. Among all 40 products, 13 products are widely used for crop protection and disease management (Table 1).

Table 1. Number of nano-enabled products, manufacturing firms, and the countries involved in plant-protection related products.

\begin{tabular}{cccc}
\hline $\begin{array}{c}\text { Nano-Enabled Products, } \\
\text { Manufacturing Firm }\end{array}$ & *NPs & Properties & Applications \\
\hline Nanocu; BioNano Technology, Egypt & $\mathrm{Cu}$ & Anti-fungal activity properties & $\begin{array}{c}\text { Use as an antifungal agent with growth } \\
\text { enhancer and improve root vigor property }\end{array}$ \\
\hline $\begin{array}{c}\text { Nano Cube }{ }^{\circledR} \text { Marinus Complete Plus } \\
\text { 30l; Dennerle, Germany }\end{array}$ & $\mathrm{Ag}$ & Algicidal properties & Applicable for management of algae \\
\hline $\begin{array}{c}\text { Blue Lagoon UV-Block; } \\
\text { Dennerle, Germany }\end{array}$ & $\mathrm{Ag}$ & Algicidal properties & $\begin{array}{c}\text { To prevent algal infection and growth in } \\
\text { agriculture ponds }\end{array}$ \\
\hline $\begin{array}{c}\text { Nanosept }{ }^{\circledR} \text { Aqua Super; } \\
\text { Nanosept, Hungary }\end{array}$ & $\mathrm{Ag}$ & $\begin{array}{c}\text { Bactericide, fungicide } \\
\text { and virucide }\end{array}$ & $\begin{array}{c}\text { Broad-spectrum plant protectant, control of } \\
\text { yield-robbing diseases }\end{array}$ \\
\hline Nanosept ${ }^{\circledR}$ Aqua; Nanosept, Hungary & $\mathrm{Ag}$ & Disinfecting agent & Broad-spectrum antimicrobial applications \\
\hline * Note: detailed information on used NPs is missing such as concentration and particle size of NPs.
\end{tabular}

\subsubsection{Nano-Pesticides}

Pesticides kill unwanted, undesirable substances like fungi, algae, and bacteria, and make plants resistant to them. The major difficulty associated with pesticides is their solubility because they are not easily soluble in water and release very slowly after spraying, thus making them ineffective [34]. Therefore, with the aid of NT, nano-pesticides enclosed within a shell made with the support of NPs are being prepared [35,36]. These nanopesticides reduce soil run-off while also increasing solubility [35,37].

\subsubsection{Nano-Insecticides}

Some insecticides are not fully soluble in water and thus, must be dissolved in organic solvents, making them toxic and also increasing the cost of the pesticide [34,38,39]. Nevertheless, the use of NPs could enhance the solubility of insecticides besides reducing toxicity. Modified chitosan and porous silica-based NPs have been effectively loaded into insecticides, and less water-soluble pesticides can be prepared [35,37,40]. In Spodoptera litura ovarian cell lines, hydrophobic insecticides such as azadirachtin with improved chitosan NPs demonstrated a promising decrease in cell proliferation and the sustained release of drugs [41]. The potential advantages of NPs were underlined in all of this research. The use of a solid-lipid mixture of NPs also solved the evaporation, or volatilization, issue correlated with the post-application of insecticide [42,43]. Insecticides applied as a mixture with NPs were observed to be useful in slowing down the release of active molecules that could help to reduce the toxic impacts of insecticides [44,45]. 


\subsubsection{Nano-Fungicides}

The most explored and beneficial NPs as fungicides are chitosan, silica, and polymer mixtures $[31,46]$. The efficacies of nano-fungicides have been noted against a variety of fungal species; however, they have rarely been tested on the crops without any toxic effects [47]. Generic insecticides possess problems such as low water solubility, poor stability, and a volatile nature that may disturb the sustained release [42]. These issues could be resolved by applying NPs-based fungicides. Low-water-soluble fungicides such as chitosan-lactide copolymer were loaded onto NPs in various concentrations, and their effectiveness was monitored as a growth inhibitor of Colletotrichum gossypii [48]. An eco-friendly alternative to current synthetic fungicides is predicted to play a major role in future plant disease management $[31,42,49]$.

In vitro tests for some repressive features of NPs such as $\mathrm{Cu}-\mathrm{NPs}, \mathrm{CuO}-\mathrm{NPs}, \mathrm{Ag}-$ $\mathrm{NPs}$, and ZnO-NPs against economically relevant foliar and soil-borne plant diseases were conducted [42]. The Cu-NPs were found to be the most effective at inhibiting mycelial development (EC50 values of 162 to $310 \mu \mathrm{g} / \mathrm{mL}$ ), followed by ZnO-NPs (EC50 values of 235 to $848 \mu \mathrm{g} / \mathrm{mL}$ ), and were practically insensitive to all fungal species, whereas Ag-NPs had a considerable inhibitory effect on Botrytis cinerea [50]. Furthermore, when NPs and their bulk equivalents were evaluated for antifungal activity, $\mathrm{ZnO}-\mathrm{NPs}$ were found to be more effective against all fungal species than $\mathrm{ZnSO}_{4}$. The $\mathrm{Cu}-\mathrm{NPs}$ were also shown to be more effective than $\mathrm{CuSO}_{4}$ against all species, excluding B. cinerea, A. alernata, and M. fructicola [50]. The absence of any link between NPs and their corresponding bulk metal and the positive association between $\mathrm{Cu}-\mathrm{NPs}$ and $\mathrm{CuO}-\mathrm{NPs}$ toxicity indicates potential changes in the mode of action between bulk- and nano-sized metals [42]. Although there is considerable diversity between fungal species, the toxicity of all NPs rose significantly when applying to spores instead of fungal hyphae [51]. This reveals that these compounds have a high potential for application as protective anti-fungal treatments.

\subsubsection{Nano-Herbicides}

Herbicides are used to kill weeds and unwanted grasses. They possess high levels of toxicity and a long half-life and are frequently unaffected by standard treatment. Generally, weeds grown along with crops affect the growth and yield of crops, and hence, traditional herbicides are applied to restrict the growth of undesired weeds. However, the application of herbicides might affect plant growth and development [52]. In this context, nano-herbicides can be effectively used to solve such type of issues [53,54]. The nanoherbicides are easily dissolved in soil particles and kill the weeds and could be designed in a form that is less hard on crops.

Nano-enabled herbicides are shown to have the remarkable potential to destroy weeds and improve crop yields [53,55]. Moreover, NPs applied as a mixture with certain herbicides such as atrazine, ametrine, triazine, and the effectiveness of these nano-enabled herbicides improved by $84 \%$ [56,57]. A commonly used herbicide to eliminate weeds and unwanted grasses is atrazine [58]. Once weeds are destroyed by herbicides, the nutrients available in the soil remain solely accessible for plants; consequently, plants develop resistance to diseases caused by nutrient deficiencies [55]. Moreover, the use of modified NPs in combination with carboxymethyl cellulose could also improve pesticide breakdown efficiency $[59,60]$.

\subsubsection{Nano-Fertilizer}

Nutrient use efficiency (NUE) is a worldwide concern due to the poor efficiency of applied nutrients [61]. Fertilizers are vital agricultural products that enhance crop production. In farming ecosystems, fertilizer contributes up to $35-40 \%$ of the productivity of any crop [62]. Without the application of fertilizers in crops, it becomes difficult to expect the required production. For this reason, a large amount of fertilizer is applied to crops in every country [63]. Due to the subsidy on fertilizers, the excess use of fertilizer has increased the amount of nitrates in groundwater, which causes nitrate pollution. In the last 
few years, use efficiencies of N, P, and K fertilizers remained constant as 30-35\%, 18-20\%, and $35-40 \%$, respectively, leaving a higher portion of added fertilizers to stay in the soil or enter the aquatic system causing eutrophication [25,64].

To resolve the problem of fertilizer accumulation, nano-enabled fertilizers could be used by regulating the release of nutrients depending on the requirement of crops. However, now, few nano-fertilizer formulations are being synthesized in China, Germany, and the USA, and few are being tested under laboratory conditions [47]. The use of nanofertilizers can increase the NUE and prevent environmental hazards [65]. Recent works also focused on carbon nanotube-based fertilizers [66]. Carbon nanotubes carry extensive surface area and could regulate moisture under the constraints of irrigation or drought conditions [47,67]. At present, more than 102 nano-enabled fertilizer products are available in the commercial market in 17 countries and have been developed by 41 companies. Among all 102 products, five nano-products are widely used in crop production (Table 2).

Table 2. Number of nanoproducts, companies, and the countries that are involved in the nano-fertilizer related nano products development.

\begin{tabular}{|c|c|c|c|}
\hline $\begin{array}{l}\text { Nano-Enabled Products, } \\
\text { Manufacturing Firm }\end{array}$ & ${ }^{*}$ NPs & Properties & Applications \\
\hline $\begin{array}{c}\text { Nano Fertilizer; Silvertech } \\
\text { Kimya Sanayi ve Ticaret Ltd., } \\
\text { Turkey }\end{array}$ & $\mathrm{ZnO}, \mathrm{TiO}_{2}$ & $\begin{array}{c}\text { Plant growth acceleration, Crop yield } \\
\text { enhancement, Photosynthesis } \\
\text { improvement }\end{array}$ & $\begin{array}{l}\text { Increase the use efficiency of plant } \\
\text { nutrients and reduce the soil toxicity }\end{array}$ \\
\hline $\begin{array}{c}\text { Nubiotek }{ }^{\circledR} \text { Hyper Fe+Mg; } \\
\text { Bioteksa, } \\
\text { Mexico }\end{array}$ & $\mathrm{Fe}, \mathrm{Mg}$ & $\begin{array}{c}\text { Nubiotek }{ }^{\circledR} \text { Hyper Fe+Mg } \\
\text { nano-enabled fertilizer functions as } \\
\text { activator improve the vegetative } \\
\text { development }\end{array}$ & $\begin{array}{l}\text { It ensures sustained growth of plants } \\
\text { in all the phenological stages, without } \\
\text { negative incidences in the production } \\
\text { due to environmental factors }\end{array}$ \\
\hline $\begin{array}{c}\text { Nubiotek }{ }^{\circledR} \text { Ultra Ca; Bioteksa, } \\
\text { Mexico }\end{array}$ & $\mathrm{Ca}$ & $\begin{array}{l}\text { Nubiotek }{ }^{\circledR} \text { Ultra Ca effectively helps } \\
\text { the crop, in general, tolerate different } \\
\text { scenarios of climatic stress, aggressive } \\
\text { presence of pests or diseases with } \\
\text { great performance }\end{array}$ & $\begin{array}{c}\text { An enantiomorphic, amiphyloid and } \\
\text { coloid that allows the Ca element to } \\
\text { penetrate quickly and effectively into } \\
\text { the tissues of the crops }\end{array}$ \\
\hline $\begin{array}{l}\text { Fértil Calmag; HPL } \\
\text { Agronegocios, Brazil }\end{array}$ & $\mathrm{Mg}$ & $\begin{array}{c}\text { Product with a high concentration of } \\
\text { Mg with high-tech liquid solution } \\
\text { of NPs }\end{array}$ & $\begin{array}{l}\text { Mg quelatizados allow a greater } \\
\text { solubility without decantation, has a } \\
\text { high concentration and high } \\
\text { availability of nutrients for plants } \\
\text { with immediate reaction }\end{array}$ \\
\hline $\begin{array}{c}\text { Nanovec TSS 80; Laboratórios } \\
\text { Bio-Médicin, Brazil }\end{array}$ & $\mathrm{Mg}, \mathrm{Mo}, \mathrm{Zn}$ & $\begin{array}{l}\text { Nanovec TSS } 80 \text { nanocapsules } \\
\text { composed of } \mathrm{Mg} \text {, Mo, and } \mathrm{Zn} \\
\text { compatible with plant cells and } \\
\text { transport nutrients into the plants } \\
\text { without loss }\end{array}$ & $\begin{array}{l}\text { Useful for leguminous plants, } \\
\text { improve germination, root systems } \\
\text { and absorbent radicels; the plant } \\
\text { absorbs more water and nutrients } \\
\text { from the soil, resisting drought } \\
\text { periods; increase number of nodules. } \\
\text { It transforms the nitrate into protein, } \\
\text { improving the use of } \mathrm{N} \text { and biological } \\
\text { fixation of nitrogen }\end{array}$ \\
\hline $\begin{array}{l}\text { Fertile Calcium 25; HPL } \\
\text { Agronegocios, Brazil }\end{array}$ & $\mathrm{Ca}$ & $\begin{array}{l}\text { Fértil Calcium } 25 \text { is easy to apply, it } \\
\text { neutralizes the phytotoxic effect of } \mathrm{Al}\end{array}$ & $\begin{array}{c}\text { It is a fluid fertilizer with a high } \\
\text { concentration of Ca with rapid root } \\
\text { absorption; it prevents diseases in Ca } \\
\text { deficient areas }\end{array}$ \\
\hline Lithocal, Litho Plant, Brazil & $\mathrm{Ca}, \mathrm{Mg}$ & $\begin{array}{l}\text { It is composed of nano-Ca and } \mathrm{Mg} \\
\text { particles, recommended for } \\
\text { application directly to the soil, in the } \\
\text { form of spraying in total area }\end{array}$ & $\begin{array}{l}\text { An essential elements for crops, } \\
\text { promoting root system, enhance } \\
\text { nutrients uptake, better resisting the } \\
\text { periods of drought, increasing } \\
\text { tillering sprouts and vegetative vigor }\end{array}$ \\
\hline
\end{tabular}


Table 2. Cont.

\begin{tabular}{|c|c|c|c|}
\hline $\begin{array}{l}\text { Nano-Enabled Products, } \\
\text { Manufacturing Firm }\end{array}$ & ${ }^{*}$ NPs & Properties & Applications \\
\hline $\begin{array}{c}\text { Fosvit K30; } \\
\text { Kimitec Group, Spain }\end{array}$ & $\mathrm{P}, \mathrm{K}$ & $\begin{array}{l}\text { Fertilizer with a high content of P } \\
\qquad(30 \%) \text { and } \mathrm{K}(20 \%)\end{array}$ & $\begin{array}{l}\text { A self-defense enhancer against } \\
\text { fungal diseases such as omicosis } \\
\text { (mildew), promotes the formation of } \\
\text { phytoalexins, it distribution K within } \\
\text { plant tissues }\end{array}$ \\
\hline $\begin{array}{c}\text { Nano Bor } 20 \% \\
\text { Alert Biotech, India }\end{array}$ & B & Used as micronutrient & $\begin{array}{l}\text { It is useful for extreme rainfall } \\
\text { regions with acidic and sandy soil } \\
\text { with deficient of organic matter }\end{array}$ \\
\hline $\begin{array}{l}\text { Nano Zinc (Soil Application } \\
\text { 21\%); Alert Biotech, India }\end{array}$ & $\mathrm{Zn}$ & $\begin{array}{l}\text { This product is intended for dealing } \\
\text { Zinc deficiency related issue of crops }\end{array}$ & $\begin{array}{l}\text { It prevented the chlorosis of rice and } \\
\text { was very effective in curing all such } \\
\text { deficiency-related issues }\end{array}$ \\
\hline $\begin{array}{l}\text { Nano Nutrients for Crops; } \\
\text { NanoLandBaltic, Lithuania }\end{array}$ & $\mathrm{SiO}_{2}$ & Product contains particles $3-50 \mathrm{~nm}$ & $\begin{array}{l}\text { Used for crops, flowers, trees, } \\
\text { and creepers, when it is sprayed on to } \\
\text { leaves it delivers all nutrients to } \\
\text { chlorophyll directly and enhance the } \\
\text { efficiency of photosynthesis }\end{array}$ \\
\hline $\begin{array}{c}\text { Nano Zinc Chelate Fertilizer; } \\
\text { AFME TRADING GROUP, } \\
\text { United Kingdom }\end{array}$ & $\mathrm{Zn}$ & Growth enhancer & $\begin{array}{l}\text { It provide one or more nutrient metal } \\
\text { elements to plants and increase the } \\
\text { growth and development }\end{array}$ \\
\hline $\begin{array}{c}\text { Nano Iron and Calcium, } \\
\text { Potassium Chelate Fertilizer; } \\
\text { Afme Trading Group, United } \\
\text { Kingdom }\end{array}$ & $\mathrm{Fe}, \mathrm{Ca}$ & $\begin{array}{l}\text { Plant growth regulater and } \\
\text { accelerater }\end{array}$ & $\begin{array}{l}\text { Helps to make up } \\
\text { for } \mathrm{Fe} / \mathrm{Ca} / \mathrm{K} \text { deficiency }\end{array}$ \\
\hline $\begin{array}{l}\text { Nano-Ag Answer }{ }^{\circledR} ; \text { Urth } \\
\text { Agriculture, USA }\end{array}$ & $\mathrm{Ag}$ & $\begin{array}{l}\text { Useful for plant and soil } \\
\text { microorganism }\end{array}$ & $\begin{array}{l}\text { It is help in plants and mycorhizal } \\
\text { fungi to uptake the nutrients and } \\
\text { eventually contribute more organic } \\
\text { matter fixation for plants }\end{array}$ \\
\hline
\end{tabular}

* Note: detailed information on used NPs are missing such as concentration and particle size of NPs.

\section{Soil Health Improvement}

These days people know that NPs are in the soil system [17,62]. After a very thorough study of the soil, researchers have found a new class of clay particles, called "Nanosols" those ranging in size from 1-100 $\mathrm{nm}$-that are more diverse than the other soil clay particles [62]. De-novo synthesized NPs have novel properties and characteristics, i.e., a very high specific surface area (SSAs) and tiny, subsequent surface charges resulting in these NPs reacting very actively with other particles in the soil matrix [62]. Due to their unique properties, NPs have a higher resistance nature, do not decompose rapidly, and accumulate slowly in the soil $[17,68]$. The aggregative nature of NPs could affect the properties of the soil. To decrease NPs' toxic effects, it is better to combine NPs with clay as a colloidal solution [69]. The constant use of urea, herbicides, and pesticides in the soil damages both the fertilizer capacity and soil health $[70,71]$. As the amount of urea, herbicides, and pesticides in the soil gradually rises above a certain concentration, they act like toxic pollutants and become harmful for both the environment and humans.

Recent studies indicated that the application of NPs improved soil enzymatic activities. Up to $200 \mathrm{mg} \mathrm{kg}^{-1}$ carbon NPs significantly improved the activities of urease, dehydrogenase, and phosphatase [72], and it also improved the storage capacity of soils for available nutrients such as ammonium N, nitrate N, and available P [72]. Multi-walled carbon nanotubes showed a stimulative impact on these soil enzymes (urease, phosphatase, and dehydrogenase) [73]. NPs can reduce the danger of soil and play a decisive role in soil management. For soil management, more than nano-enabled products are normally available on the commercial market and can be found in three countries as developed 
by three companies. These companies' products (Descal, Humic 101, Coco: flower, Coco: grow, Hydro: flower, Soilklik) do not add sufficient details regarding product applications.

\section{Plant Uptake and Translocation of Nano-Enabled Products}

This section discusses plants' uptake of water and dissolved solutes from the root to the top of the plant through translocation. The transpiration-cohesion-tension mechanism and root pressure play a major role in raising water to the top of plants through the vascular tissue system, primarily from xylem. Soil solutions with higher water potential compared to root hair cells pass into cortical cells, through the endodermis and the pericycle, and then into the xylem vessels. This whole process of translocation depends on water potential. Likewise, the exposure of NPs in the soil first interacted with the plant cell wall and cell membrane of the root epidermis. Through a complex plant uptake mechanism, NPs enter into the plant vascular bundle (xylem) and translocate into leaves (Figure 2). The absorption of NPs from the soil is also considered a primary step of the bioaccumulation of NPs into the plant system [74]. Once NPs penetrate the plant cells and are transported into the plant tissue, there are two pathways for transportation: the apoplast and the symplast [75].

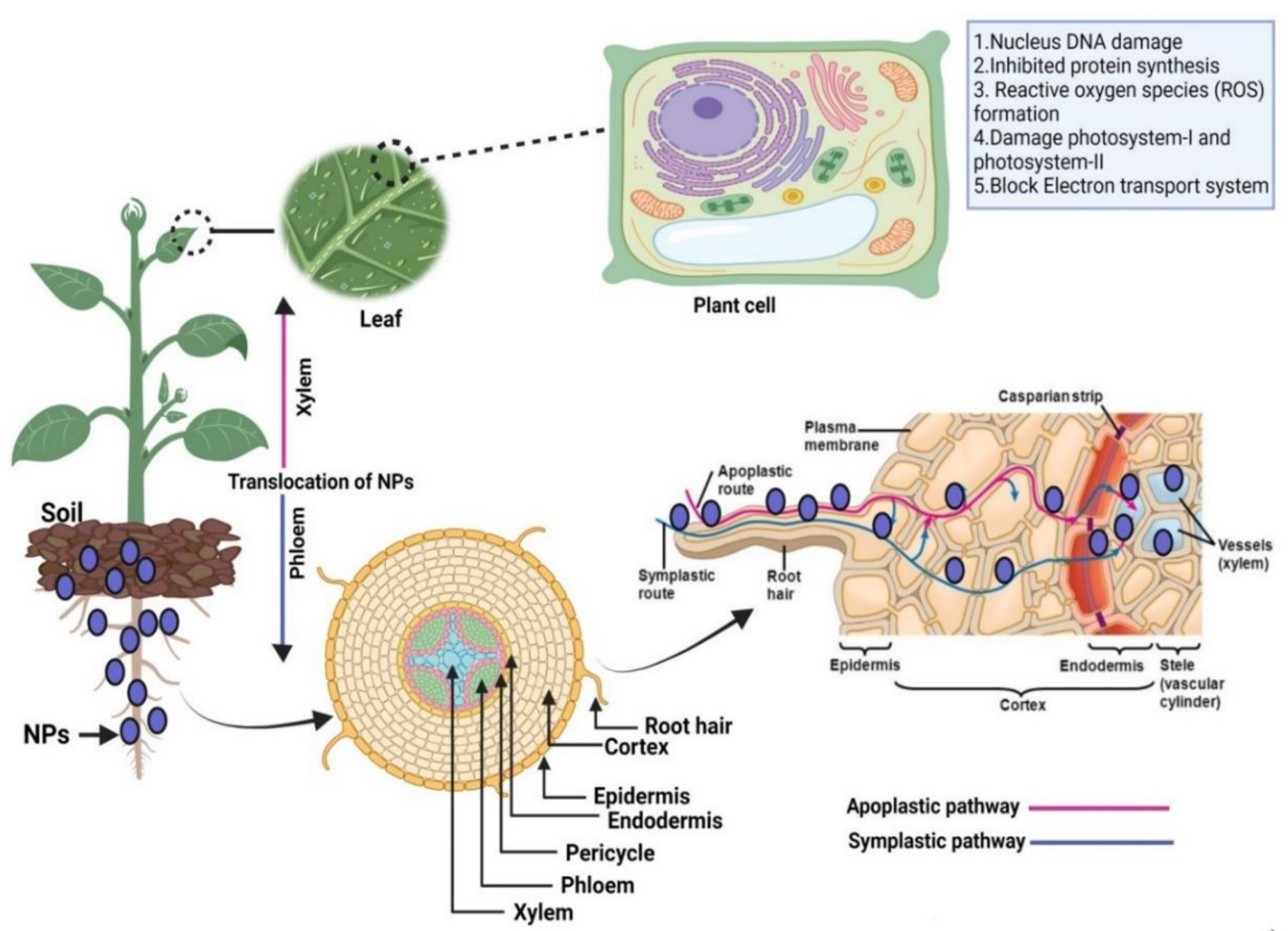

Figure 2. Uptake and translocation of nanoparticles by plant tissues: nanoparticles interact with plant roots, translocate through the epidermis, cortex, endodermis, and pericycle and then into xylem vessels via apoplastic and symplastic pathways.

In the apoplastic pathway, NPs are transported outside the plasma membrane through the extracellular spaces, cell walls of adjacent cells, and xylem vessels [76]. Symplast transportation movement of NPs takes place between the cytoplasm of adjacent cells through specialized structures called plasmodesmata and sieve plates [77].

The translocation of NPs through apoplastic pathways is essential for radial movement within plant tissue that allows NPs to reach the vascular tissue system that aids in further movement of NPs through the xylem in various parts of the plant tissue $[75,78,79]$. As the application of NPs is increasing in agriculture, it has become very important to know how they are transported and interact with plants' roots and their organelles. Accurate information regarding the translocation pathways of NPs in plant cells could provide an improved understanding of the transportation of NPs via phloem or xylem. It could also 
help to understand their accumulation in plant organs acting as sinks, such as fruits and grains, so that in the future, it is easy to detect NP accumulation and assess the toxicity and to avoid it by designing nano-enabled products to reduce the accumulation of NPs in plant cells. Consequently, it could be used to reduce their effects, such as altering various biological processes (Figure 2).

\section{Conclusions and Concerns Associated with Nano-Enabled Products}

The major concerns that arise with nano-enabled products are about the potential concentration of NPs used because, at higher concentrations, NPs showed toxic effects at various levels. The continuous application of nano-enabled products, especially in agriculture, could increase their content in soil and in crops. Most of the nano-enabled products shown in the tables / figure do not reveale the used concentration, particle size, name, and synthesis methods of applied NPs. Nanoparticles could be transferred from root to leaf and leaf to root, thus entering into the food chain. Moreover, they exhibit large-scale bioretention and accumulation within living organisms, possibly beyond safe levels. Even a certain quantity of NPs could be harmful to human health. Higher levels of toxicity can cause growth retardation and inhibition. However, the toxicity of NPs is specific to the shape, size, concentrations, base materials, and coatings. There is an extensive range of nano-enabled products in use that could be broken down into a different class of compound such as metals, metal-oxides, carbon, and semi-conductor materials and could generate new types of hazardous pollutants. To address these issues, green nanotechnology is a multidisciplinary field that is creating clean, safe, and environmentally friendly alternatives to products being currently used in various different industries. As their name signifies, they are derived from different plant parts, microorganisms, amino acids, glucose, etc. They suggest improving the commercial readiness of these technologies. The current review explored the use of nano-enabled products and discovered some interesting features based on recent findings. However, additional scientific evidence regarding these or new nanoenabled products is required. The studies should be directed towards determining the underlying mechanisms of nano-enabled products' interplay with the food chain, as well as their epigenetic consequences.

Author Contributions: Conceptualization, V.D.R., A.S., T.M. and S.R., methodology, V.D.R. and A.S.; software, V.D.R., A.S. and T.M.; validation, V.D.R. and T.M.; formal analysis, S.S., S.M., P.R. and A.K.S.; investigation, resources.; data curation, writing-original draft preparation, V.D.R., A.S., T.M., S.R., S.M., S.S., V.S., O.N., P.R., K., K.K.V., A.K.S., M.R. and S.K.U.; visualization, T.M. and S.M.; supervision T.M., project administration, T.M., S.S., and S.M.; funding acquisition, V.S., T.M., V.D.R. and S.M. All authors have read and agreed to the published version of the manuscript.

Funding: Not applicable.

Institutional Review Board Statement: Not applicable.

Informed Consent Statement: Not applicable.

Data Availability Statement: Not applicable.

Acknowledgments: The research was financially supported by the Russian Science Foundation, project no. 21-77-20089.

Conflicts of Interest: The authors declare no conflict of interest.

\section{References}

1. Chokheli, V.; Rajput, V.; Dmitriev, P.; Varduny, T.; Minkina, T.; Singh, R.K.; Singh, A. Status and policies of GM crops in Russia. In Policy Issues in Genetically Modified Crops; Singh, P., Borthakur, A., Singh, A.A., Kumar, A., Singh, K.K., Eds.; Academic Press: Cambridge, UK, 2021; pp. 57-74.

2. Rizwan, M.; Ali, S.; Qayyum, M.F.; Ok, Y.S.; Adrees, M.; Ibrahim, M.; Zia-Ur-Rehman, M.; Farid, M.; Abbas, F. Effect of metal and metal oxide nanoparticles on growth and physiology of globally important food crops: A critical review. J. Hazard. Mater. 2017, 322, 2-16. [CrossRef] [PubMed]

3. Feynman, R.P. There's Plenty of Room at the Bottom. Eng. Sci. 1960, 23, 22-36. 
4. Taniguchi, N. Nanotechnology: Integrated Processing Systems for Ultra-Precision and Ultra-FINE products; Oxford Univ. Press: Oxford, UK, 1996.

5. NNI-Budget. National Nanotechnology Initiative. 2021. Available online: https://www.nano.gov/about-nni/what/funding (accessed on 20 July 2021).

6. $\quad$ Rajput, V.D.; Minkina, T.; Kumari, A.; Harish; Singh, V.K.; Verma, K.K.; Mandzhieva, S.; Sushkova, S.; Srivastava, S.; Keswani, C. Coping with the challenges of abiotic stress in plants: New dimensions in the field application of nanoparticles. Plants 2021, 10, 1221. [CrossRef] [PubMed]

7. Khan, M.K.; Pandey, A.; Hamurcu, M.; Gezgin, S.; Athar, T.; Rajput, V.D.; Gupta, O.P.; Minkina, T. Insight into the prospects for nanotechnology in wheat biofortification. Biology 2021, 10, 1123. [CrossRef] [PubMed]

8. Chauhan, R.; Yadav, H.O.S.; Sehrawat, N. Nanobioremediation: A new and a versatile tool for sustainable environmental clean up-Overview. J. Mater. Environ. Sci. 2020, 11, 564-573.

9. Cecchin, I.; Reddy, K.R.; Thomé, A.; Tessaro, E.F.; Schnaid, F. Nanobioremediation: Integration of nanoparticles and bioremediation for sustainable remediation of chlorinated organic contaminants in soils. Int. Biodeterior. Biodegrad. 2017, 119, 419-428. [CrossRef]

10. Rizwan, M.; Singh, M.; Mitra, C.K.; Morve, R.K. Ecofriendly application of nanomaterials: Nanobioremediation. J. Nanoparticles 2014, 2014, 431787. [CrossRef]

11. Shende, S.; Rajput, V.; Gade, A.; Minkina, T.; Sushkova, S.N.; Mandzhieva, S.S.; Boldyreva, V.E. Metal-based green synthesized nanoparticles: Boon for sustainable agriculture and food security. IEEE Trans. NanoBioscience 2021, 1. [CrossRef] [PubMed]

12. Knijnenburg, J.T.N.; Posavec, L.; Teleki, A. Nanostructured minerals and vitamins for food fortification and food supplementation. In Nanomaterials for Food Applications; Elsevier: Amsterdam, The Netherlands, 2019; pp. 63-98.

13. Shafiq, M.; Anjum, S.; Hano, C.; Anjum, I.; Abbasi, B.H. An overview of the applications of nanomaterials and nanodevices in the food industry. Foods 2020, 9, 148. [CrossRef]

14. Raliya, R.; Saharan, V.; Dimkpa, C.; Biswas, P. Nanofertilizer for precision and sustainable agriculture: Current state and future perspectives. J. Agric. Food Chem. 2017. [CrossRef]

15. Sharma, P.; Bhatt, D.; Zaidi, M.G.; Saradhi, P.P.; Khanna, P.K.; Arora, S. Silver nanoparticle-mediated enhancement in growth and antioxidant status of Brassica juncea. Appl. Biochem. Biotechnol. 2012, 167, 2225-2233. [CrossRef] [PubMed]

16. Shende, S.S.; Rajput, V.D.; Gorovtsov, A.V.; Harish; Saxena, P.; Minkina, T.M.; Chokheli, V.A.; Jatav, H.S.; Sushkova, S.N.; Kaur, P.; et al. Interaction of nanoparticles with microbes. In Plant-Microbes-Engineered Nano-Particles (PM-ENPs) Nexus in AgroEcosystems: Understanding the Interaction of Plant, Microbes and Engineered Nano-Particles (ENPS); Singh, P., Singh, R., Verma, P., Bhadouria, R., Kumar, A., Kaushik, M., Eds.; Springer International Publishing: Cham, Switzerland, 2021; pp. 175-188.

17. Rajput, V.D.; Singh, A.; Singh, V.K.; Minkina, T.M.; Sushkova, S. Impact of nanoparticles on soil resource. In Nanomaterials for Soil Remediation; Amrane, A., Mohan, D., Nguyen, T.A., Assadi, A.A., Yasin, G., Eds.; Elsevier: Amsterdam, The Netherlands, 2021; pp. 65-85.

18. Duncan, T.V. Applications of nanotechnology in food packaging and food safety: Barrier materials, antimicrobials and sensors. J. Colloid. Interface Sci. 2011, 363, 1-24. [CrossRef] [PubMed]

19. Rajput, V.; Minkina, T.; Mazarji, M.; Shende, S.; Sushkova, S.; Mandzhieva, S.; Burachevskaya, M.; Chaplygin, V.; Singh, A.; Jatav, H. Accumulation of nanoparticles in the soil-plant systems and their effects on human health. Ann. Agric. Sci. 2020, 65, 137-143. [CrossRef]

20. Ali, S.S.; Al-Tohamy, R.; Koutra, E.; Moawad, M.S.; Kornaros, M.; Mustafa, A.M.; Mahmoud, Y.A.G.; Badr, A.; Osman, M.E.H.; Elsamahy, T.; et al. Nanobiotechnological advancements in agriculture and food industry: Applications, nanotoxicity, and future perspectives. Sci. Total. Environ. 2021, 792, 148359. [CrossRef]

21. Yadav, R.K.; Singh, N.B.; Singh, A.; Yadav, V.; Bano, C.; Khare, S.; Vegetas, N. Expanding the horizons of nanotechnology in agriculture: Recent advances, challenges and future perspectives. Vegetos 2020, 33, 203-221. [CrossRef]

22. Usman, M.; Farooq, M.; Wakeel, A.; Nawaz, A.; Cheema, S.A.; Rehman, H.u.; Ashraf, I.; Sanaullah, M. Nanotechnology in agriculture: Current status, challenges and future opportunities. Sci. Total. Environ. 2020, 721, 137778. [CrossRef]

23. Schwab, F.; Zhai, G.; Kern, M.; Turner, A.; Schnoor, J.L.; Wiesner, M.R. Barriers, pathways and processes for uptake, translocation and accumulation of nanomaterials in plants-Critical review. Nanotoxicology 2016, 10, 257-278. [CrossRef]

24. Biju, V.; Itoh, T.; Anas, A.; Sujith, A.; Ishikawa, M. Semiconductor quantum dots and metal nanoparticles: Syntheses, optical properties, and biological applications. Anal. Bioanal. Chem. 2008, 391, 2469-2495. [CrossRef] [PubMed]

25. Shang, Y.; Hasan, M.K.; Ahammed, G.J.; Li, M.; Yin, H.; Zhou, J. Applications of nanotechnology in plant growth and crop protection: A review. Molecules 2019, 24, 2558. [CrossRef] [PubMed]

26. Duhan, J.S.; Kumar, R.; Kumar, N.; Kaur, P.; Nehra, K.; Duhan, S. Nanotechnology: The new perspective in precision agriculture. Biotechnol. Rep. Amst. 2017, 15, 11-23. [CrossRef]

27. Petosa, A.R.; Rajput, F.; Selvam, O.; Öhl, C.; Tufenkji, N. Assessing the transport potential of polymeric nanocapsules developed for crop protection. Water Res. 2017, 111, 10-17. [CrossRef] [PubMed]

28. Kashyap, P.L.; Xiang, X.; Heiden, P. Chitosan nanoparticle based delivery systems for sustainable agriculture. Int. J. Biol. Macromol. 2015, 77, 36-51. [CrossRef] 
29. Faizan, M.; Sehar, S.; Rajput, V.D.; Faraz, A.; Afzal, S.; Minkina, T.; Sushkova, S.; Adil, M.F.; Yu, F.; Alatar, A.A.; et al. Modulation of cellular redox status and antioxidant defense system after synergistic application of Zinc oxide nanoparticles and salicylic acid in rice (Oryza sativa) plant under arsenic stress. Plants 2021, 10, 2254. [CrossRef] [PubMed]

30. Khot, L.R.; Sankaran, S.; Maja, J.M.; Ehsani, R.; Schuster, E.W. Applications of nanomaterials in agricultural production and crop protection: A review. Crop Prot. 2012, 35, 64-70. [CrossRef]

31. Prasad, R.; Bhattacharyya, A.; Nguyen, Q.D. Nanotechnology in sustainable agriculture: Recent developments, challenges, and perspectives. Front. Microbiol. 2017, 8. [CrossRef] [PubMed]

32. Ranjan, A.; Rajput, V.D.; Minkina, T.; Bauer, T.; Chauhan, A.; Jindal, T. Nanoparticles induced stress and toxicity in plants. Environ. Nanotechnol. Monit. Manag. 2021, 15, 100457. [CrossRef]

33. Marcous, A.; Rasouli, S.; Ardestani, F. Low-density polyethylene films loaded by titanium dioxide and zinc oxide nanoparticles as a new active packaging system against Escherichia coli O157:H7 in fresh calf minced meat. Packag. Technol. Sci. 2017, 30, 693-701. [CrossRef]

34. Lushchak, V.I.; Matviishyn, T.M.; Husak, V.V.; Storey, J.M.; Storey, K.B. Pesticide toxicity: A mechanistic approach. EXCLI J. 2018, 17, 1101-1136. [CrossRef]

35. Chaud, M.; Souto, E.B.; Zielinska, A.; Severino, P.; Batain, F.; Oliveira-Junior, J.; Alves, T. Nanopesticides in agriculture: Benefits and challenge in agricultural productivity, toxicological risks to human health and environment. Toxics 2021, 9, 131. [CrossRef] [PubMed]

36. Zobir, S.A.; Ali, A.; Adzmi, F.; Sulaiman, M.R.; Ahmad, K. A review on nanopesticides for plant protection synthesized using the supramolecular chemistry of layered hydroxide hosts. Biology 2021, 10, 1077. [CrossRef] [PubMed]

37. Huang, B.; Chen, F.; Shen, Y.; Qian, K.; Wang, Y.; Sun, C.; Zhao, X.; Cui, B.; Gao, F.; Zeng, Z.; et al. Advances in targeted pesticides with environmentally responsive controlled release by nanotechnology. Nanomaterials 2018, 8, 102. [CrossRef] [PubMed]

38. Herrmann, J.-M.; Guillard, C. Photocatalytic degradation of pesticides in agricultural used waters. Comptes Rendus De L'académie Des Sci. Ser. IIC Chem. 2000, 3, 417-422. [CrossRef]

39. Karimi, H.; Mahdavi, S.; Asgari Lajayer, B.; Moghiseh, E.; Rajput, V.D.; Minkina, T.; Astatkie, T. Insights on the bioremediation technologies for pesticide-contaminated soils. Environ. Geochem. Health 2021, in press. [CrossRef] [PubMed]

40. Etesami, H. Can interaction between silicon and plant growth promoting rhizobacteria benefit in alleviating abiotic and biotic stresses in crop plants? Agric. Ecosyst. Environ. 2018, 253, 98-112. [CrossRef]

41. Lu, W.; Lu, M.-L.; Zhang, Q.-P.; Tian, Y.-Q.; Zhang, Z.-X.; Xu, H.-H. Octahydrogenated retinoic acid-conjugated glycol chitosan nanoparticles as a novel carrier of azadirachtin: Synthesis, characterization, and in vitro evaluation. J. Polym. Sci. Part A Polym. Chem. 2013, 51, 3932-3940. [CrossRef]

42. Worrall, E.A.; Hamid, A.; Mody, K.T.; Mitter, N.; Pappu, H.R. Nanotechnology for plant disease management. Agronomy 2018, 8, 285. [CrossRef]

43. Servin, A.; Elmer, W.; Mukherjee, A.; De la Torre-Roche, R.; Hamdi, H.; White, J.C.; Bindraban, P.; Dimkpa, C. A review of the use of engineered nanomaterials to suppress plant disease and enhance crop yield. J. Nanoparticle Res. 2015, 17, 92. [CrossRef]

44. de Oliveira, J.L. Nano-biopesticides: Present concepts and future perspectives in integrated pest management. In Advances in Nano-Fertilizers and Nano-Pesticides in Agriculture; Jogaiah, S., Singh, H.B., Fraceto, L.F., Lima, R.d., Eds.; Woodhead Publishing: Sawston, UK, 2021; pp. 1-27.

45. Okey-Onyesolu, C.F.; Hassanisaadi, M.; Bilal, M.; Barani, M.; Rahdar, A.; Iqbal, J.; Kyzas, G.Z. Nanomaterials as nanofertilizers and nanopesticides: An overview. ChemistrySelect 2021, 6, 8645-8663. [CrossRef]

46. Faizan, M.; Rajput, V.D.; Al-Khuraif, A.A.; Arshad, M.; Minkina, T.; Sushkova, S.; Yu, F. Effect of foliar fertigation of chitosan nanoparticles on cadmium accumulation and toxicity in Solanum lycopersicum. Biology 2021, 10, 666. [CrossRef] [PubMed]

47. Vishwakarma, K.; Upadhyay, N.; Kumar, N.; Tripathi, D.K.; Chauhan, D.K.; Sharma, S.; Sahi, S. Potential applications and avenues of nanotechnology in sustainable agriculture. In Nanomaterials in Plants, Algae, and Microorganisms; Tripathi, D.K., Ahmad, P., Sharma, S., Chauhan, D.K., Dubey, N.K., Eds.; Academic Press: Cambridge, MA, USA, 2018; pp. 473-500.

48. Xu, L.; Cao, L.-D.; Li, F.-M.; Wang, X.-J.; Huang, Q.-L. Utilization of chitosan-lactide copolymer nanoparticles as controlled release pesticide carrier for pyraclostrobin against colletotrichum Gossypii southw. J. Dispers. Sci. Technol. 2014, 35, 544-550. [CrossRef]

49. Hernandez-Diaz, J.A.; Garza-Garcia, J.J.; Zamudio-Ojeda, A.; Leon-Morales, J.M.; Lopez-Velazquez, J.C.; Garcia-Morales, S. Plant-mediated synthesis of nanoparticles and their antimicrobial activity against phytopathogens. J. Sci. Food Agric. 2020, 101, 1270-1287. [CrossRef] [PubMed]

50. Malandrakis, A.A.; Kavroulakis, N.; Chrysikopoulos, C.V. Use of copper, silver and zinc nanoparticles against foliar and soil-borne plant pathogens. Sci. Total. Environ. 2019, 670, 292-299. [CrossRef]

51. Chen, J.; Wu, L.; Lu, M.; Lu, S.; Li, Z.; Ding, W. Comparative Study on the Fungicidal Activity of Metallic MgO Nanoparticles and Macroscale MgO Against Soilborne Fungal Phytopathogens. Front. Microbiol. 2020, 11. [CrossRef] [PubMed]

52. Sangakkara, U.R.; Stamp, P. Influence of different weed categories on growth and yields of maize (Zea mays) grown in a minor (dry) season of the humid tropics/Einfluss verschiedener Schadpflanzengruppen auf Wachstum und Ertrag von Mais (Zea mays) in einer humiden Tropenzone während der Trockenzeit. J. Plant Dis. Prot. 2006, 113, 81-85.

53. Song, G.; Hou, W.; Gao, Y.; Wang, Y.; Lin, L.; Zhang, Z.; Niu, Q.; Ma, R.; Mu, L.; Wang, H. Effects of CuO nanoparticles on Lemna minor. Bot. Stud. 2016, 57, 3. [CrossRef] [PubMed] 
54. Lalau, C.M.; Mohedano Rde, A.; Schmidt, E.C.; Bouzon, Z.L.; Ouriques, L.C.; dos Santos, R.W.; da Costa, C.H.; Vicentini, D.S.; Matias, W.G. Toxicological effects of copper oxide nanoparticles on the growth rate, photosynthetic pigment content, and cell morphology of the duckweed Landoltia punctata. Protoplasma 2015, 252, 221-229. [CrossRef] [PubMed]

55. Rajput, V.D.; Singh, A.; Minkina, T.M.; Shende, S.S.; Kumar, P.; Verma, K.K.; Bauer, T.; Gorobtsova, O.; Deneva, S.; Sindireva, A. Potential applications of nanobiotechnology in plant nutrition and protection for sustainable agriculture. In Nanotechnology in Plant Growth Promotion and Protection; John Wiley \& Sons Ltd.: Hoboken, NJ, USA, 2021; pp. 79-92.

56. Patra, J.K.; Das, G.; Fraceto, L.F.; Campos, E.V.R.; Rodriguez-Torres, M.D.P.; Acosta-Torres, L.S.; Diaz-Torres, L.A.; Grillo, R.; Swamy, M.K.; Sharma, S.; et al. Nano based drug delivery systems: Recent developments and future prospects. J. Nanobiotechnol. 2018, 16, 71. [CrossRef]

57. Fraceto, L.F.; Grillo, R.; de Medeiros, G.A.; Scognamiglio, V.; Rea, G.; Bartolucci, C. Nanotechnology in agriculture: Which innovation potential does it have? Front. Environ. Sci. 2016, 4. [CrossRef]

58. He, H.; Liu, Y.; You, S.; Liu, J.; Xiao, H.; Tu, Z. A review on recent treatment technology for herbicide atrazine in contaminated environment. Int. J. Environ. Res. Public Health 2019, 16, 5129. [CrossRef]

59. Nandhini, A.R.; Harshiny, M.; Gummadi, S.N. Chlorpyrifos in environment and food: A critical review of detection methods and degradation pathways. Environ. Sci. Process. Impacts 2021, 23, 1255-1277. [CrossRef] [PubMed]

60. Akalin, G.O.; Pulat, M. Controlled release behavior of zinc-loaded carboxymethyl cellulose and carrageenan hydrogels and their effects on wheatgrass growth. J. Polym. Res. 2020, 27, 1-11. [CrossRef]

61. Congreves, K.A.; Otchere, O.; Ferland, D.; Farzadfar, S.; Williams, S.; Arcand, M.M. Nitrogen use efficiency definitions of today and tomorrow. Front. Plant Sci. 2021, 12. [CrossRef] [PubMed]

62. Ghasabkolaei, N.; Janalizadeh Choobbasti, A.; Roshan, N.; Ghasemi, S.E. Geotechnical properties of the soils modified with nanomaterials: A comprehensive review. Arch. Civ. Mech. Eng. 2017, 17, 639-650. [CrossRef]

63. Chen, H.; Yada, R. Nanotechnologies in agriculture: New tools for sustainable development. Trends Food Sci. Technol. 2011, 22, 585-594. [CrossRef]

64. Iqbal, M.; Umar, S.; Mahmooduzzafar. Nano-fertilization to enhance nutrient use efficiency and productivity of crop plants. In Nanomaterials and Plant Potential; Husen, A., Iqbal, M., Eds.; Springer International Publishing: Cham, Switzerland, 2019; pp. 473-505.

65. Mejias, J.H.; Salazar, F.; Pérez Amaro, L.; Hube, S.; Rodriguez, M.; Alfaro, M. Nanofertilizers: A cutting-edge approach to increase nitrogen use efficiency in grasslands. Front. Environ. Sci. 2021, 9. [CrossRef]

66. Shekhawat, G.S.; Mahawar, L.; Rajput, P.; Rajput, V.D.; Minkina, T.; Singh, R.K. Role of engineered carbon nanoparticles (CNPs) in promoting growth and metabolism of Vigna radiata (L.) Wilczek: Insights into the biochemical and physiological responses. Plants 2021, 10, 1317. [CrossRef] [PubMed]

67. Karami, A.; Sepehri, A. Beneficial role of MWCNTs and SNP on growth, physiological and photosynthesis performance of barley under $\mathrm{NaCl}$ stress. J. Soil Sci. Plant Nutr. 2018, 18, 752-771. [CrossRef]

68. Kumari, A.; Kumari, P.; Rajput, V.D.; Sushkova, S.N.; Minkina, T. Metal(loid) nanosorbents in restoration of polluted soils: Geochemical, ecotoxicological, and remediation perspectives. Environ. Geochem. Health 2021, in press. [CrossRef] [PubMed]

69. Iranpour, B.; Haddad, A. The influence of nanomaterials on collapsible soil treatment. Eng. Geol. 2016, 205, 40-53. [CrossRef]

70. Joko, T.; Anggoro, S.; Sunoko, H.R.; Rachmawati, S. Pesticides usage in the soil quality degradation potential in Wanasari Subdistrict, Brebes, Indonesia. Appl. Environ. Soil Sci. 2017, 2017, 5896191. [CrossRef]

71. Prashar, P.; Shah, S. Impact of fertilizers and pesticides on soil microflora in agriculture. In Sustainable Agriculture Reviews: Volume 19; Lichtfouse, E., Ed.; Springer International Publishing: Cham, Switzerland, 2016; pp. 331-361.

72. Zhao, F.; Xin, X.; Cao, Y.; Su, D.; Ji, P.; Zhu, Z.; He, Z. Use of carbon nanoparticles to improve soil fertility, crop growth and nutrient uptake by corn (Zea mays L.). Nanomaterials 2021, 11, 2717. [CrossRef] [PubMed]

73. Xin, X.; Zhao, F.; Zhao, H.; Goodrich, S.L.; Hill, M.R.; Sumerlin, B.S.; Stoffella, P.J.; Wright, A.L.; He, Z. Comparative assessment of polymeric and other nanoparticles impacts on soil microbial and biochemical properties. Geoderma 2020, 367, 114278. [CrossRef]

74. Nair, R. Plant response Strategies to engineered metal oxide nanoparticles: A review. In Phytotoxicity of Nanoparticles; Springer: Cham, Switzerland, 2018; pp. 377-393. [CrossRef]

75. Pérez-de-Luque, A. Interaction of nanomaterials with plants: What do we need for real applications in agriculture? Front. Environ. Sci. 2017, 5. [CrossRef]

76. Rajput, V.D.; Minkina, T.M.; Behal, A.; Sushkova, S.N.; Mandzhieva, S.; Singh, R.; Gorovtsov, A.; Tsitsuashvili, V.S.; Purvis, W.O.; Ghazaryan, K.A.; et al. Effects of zinc-oxide nanoparticles on soil, plants, animals and soil organisms: A review. Environ. Nanotechnol. Monit. Manag. 2018, 9, 76-84. [CrossRef]

77. Sevilem, I.; Miyashima, S.; Helariutta, Y. Cell-to-cell communication via plasmodesmata in vascular plants. Cell Adh. Migr. 2013, 7, 27-32. [CrossRef] [PubMed]

78. Fiol, D.F.; Terrile, M.C.; Frik, J.; Mesas, F.A.; Álvarez, V.A.; Casalongué, C.A. Nanotechnology in plants: Recent advances and challenges. J. Chem. Technol. Biotechnol. 2021, 96, 2095-2108. [CrossRef]

79. Rajput, V.; Minkina, T.; Fedorenko, A.; Sushkova, S.; Mandzhieva, S.; Lysenko, V.; Duplii, N.; Fedorenko, G.; Dvadnenko, K.; Ghazaryan, K. Toxicity of copper oxide nanoparticles on spring barley (Hordeum sativum distichum). Sci. Total. Environ. 2018, 645, 1103-1113. [CrossRef] [PubMed] 